\title{
REFLEXIONES CONSTITUCIONALES SOBRE EL HECHO ECONOMICO
}

\author{
Manuel María Zorrilla Ruiz \\ Catedrático de la Universidad de Deusto
}

Sumario: 1. Interés del Pr. CE en materia económica. 2. Establecimiento de un orden económico justo. 3. Economía y vida en dignidad. 4. Significado económico de la sociedad avanzada. 5. Valores superiores del ordenamiento jurídico y valores económicos. 6. Cláusula transformadora y social. 7. Lecturas del art. 1.1. CE. 8. ¿Moralización de la economía? 9. Principios rectores de la política social y económica. 10. Manipulación del interés general. 11. Ingerencia económica y progreso social. 12. Planificación y política económica. 13. Consolidación conceptual de la libertad de empresa.

\section{Interés del Pr. CE en materia económica}

El Pr. CE ofrece especial interés a causa de su significación decisionista en materias de naturaleza económica, aunque - como contrapunto a esta singularidad- su utilidad interpretativa sea menor o secundaria. La redacción de dicho texto fue obra de un grupo reducido de expertos que no participaron en la elaboración del texto constitucional y que, a modo de encargo indemnizatorio tardío, consiguieron cierta paternidad de adopción, con la que, de paso, quiso compensarse — tan simbólicamente como estérilmente - a alguna figura cuya honorabilidad filosófica y política no bastó para acordar su incorporación a unas tareas - las de la legislación constituyente- de que le marginaron sus correligionarios.

El Pr. CE no refleja, por definición, el cúmulo de vivencias y/o tensiones que acompañaron a la propuesta, debate y enunciado final de los contenidos económicos constitucionales, ni informa del ambiente en que fueron gestados, ni evoca o hace acopio de las incidencias precedentes, ni señala las pautas de compromiso o de consenso adoptadas para aceptar 
las soluciones que prevalecieron. Trátase de un pasaje que predice - con todo el énfasis puesto en ello por sus redactores - futuros momentos sociales, augura un espíritu móvil de la carta política e intuye el papel que asume en relación a la sociedad democrática avanzada que la dec. 5 Pr. CE promete implantar. Se considera que, no obstante la enérgica consigna de transformación estampada en el art. 9.2. CE, la factura del texto constitucional no se condice con la cumplida ejecución de este propósito, porque la carta política adolece de un ingrediente conservador que frena el ritmo acelerado de cualquier empresa de progreso.

Para la dec. 5 Pr. CE, ni la sociedad avanzada resulta directamente del juego normativo del texto recién estrenado, ni es éste un producto perenne y avalado por el esfuerzo del consenso, sino un instrumento de cierto eclecticismo, que, con el tiempo, debe ceder ante una regulación más ambiciosa y adecuada al modelo social que se anuncia. La obra del legislador constituyente se impregna así de provisionalidad y queda a la espera - utópica espera- de un cambio sustancial.

\section{Establecimiento de un orden económico justo}

Esas orientaciones económicas dependen de la dec. 1 Pr. CE, cuyo objetivo es fundar en un orden económico justo la convivencia democrática o modo de existir de cada uno de los grupos que, en el todo del conflicto social, ocupan los respectivos espacios habitables y logran el reconocimiento de su propia fisonomía. El art. 9.2. CE — que contribuye a distinguir la comunidad o agregación de cuerpos intermedios, del pueblo que, según el art. 1.2. CE, es titular originario del poder político y está formado por la suma aritmética de las personas físicas de que se compone- concibe aquélla como resultante de la coexistencia espontánea, no exenta de tensiones, de los diversos grupos en que se integra el individuo. No en vano, el art. 20.3 CE evoca, tan de pasada como significativamente, la importancia del respeto debido al pluralismo de la sociedad.

La pretensión de que esas colectividades aglutinen y/o armonicen sus acciones mediante opciones económicas justas, se ha de satisfacer - como quiera la dec. 1 Pr. CE- dentro de la Constitución y de las leyes. Se tiende a que, frente a la obstinación voluntarista del positivismo legal, las operaciones de aplicación de la ley fundamental y de difusión del sentimiento constitucional - básicos para edificar el orden económico deseado- respondan al diseño intelectualista de la ley. Se está enmendando la plana a la cortedad con que el art. 40.1 CE - cuya escasez moral se infiere de esta comparación-elude llegar a un compromiso máximo con la justicia de tal orden de cosas y ciñe la acción de los poderes 
públicos a promover las condiciones más favorables — que no son necesariamente las más justas - para el progreso económico de la sociedad. La dec. 1. Pr. CE censura la estrechez con que el constituyente - criticado por los adoptantes de su propia obra- sólo exige, en esta y otras ocasiones, el cumplimiento de obligaciones de medios o de simple actividad, que liberan fácilmente de responsabilidades y reproches cuando el balance de las acciones públicas es insatisfactorio e inclusive funesto. Basta que, como conviene al carácter de dichos deberes, el poder público demuestre - aun cuando el módico talento de los beneficiarios de la excusa les ha privado de ampararse en ella- que su desafortunada gestión no ha sido fruto de absoluta imprevisión o apresuramiento temerario, al proponerse un resultado extraordinariamente difícil de alcanzar.

\section{Economía y vida en dignidad}

La dec. 4 Pr. CE — que proclama la voluntad nacional de promover el progreso de la economía para asegurar a todos una digna calidad de vida- quiere decir que la política económica — normativamente incorporada al acervo legislativo material que identifica el art. $149.1 \mathrm{n} .^{\circ} 13 .^{\circ}$ $\mathrm{CE}$ - se subordina a las políticas de signo individual o social proyectadas para acelerar el que, en una divagación reveladora, el art. 27.2 CE llama desarrollo pleno de la personalidad humana. La calidad de vida - a que se endereza la acción económica y en cuya virtud sus iniciativas adquieren sentido- no es una calidad cualquiera y/o estereotipada en quién sabe qué recetas demagógicas o fórmulas de intoxicación colectiva, sino que ha de ser digna o adecuada al respeto del ser personal, no a condiciones adjetivas o triviales de sus beneficiarios. Se vive en dignidad cuando es real y no declamatorio el valor de la cosmoeminencia individual, cuando se reconoce y robustece la supremacía que su cualidad de ser creado le otorga respecto de cuanto, estando también en el mundo, depende de esa jerarquía y queda ordenado a su servicio.

Se descalifican las opciones económicas que imponen una existencia personal sojuzgada o indigna, o destituyen a esa vida del mínimo de calidad - posesión y continuidad del sentimiento de propia estimación-que debe caracterizarla. El art. 45. 2 CE alude a una variante - la utilización racional de todos los recursos naturales - que es parte del medio antropocéntrico en que una digna calidad de vida debe reconocerse.

Vivir en dignidad supone que, a la luz del art. 10.1 CE, el proyecto personal — de que todo ser humano es capaz- se arregla a los valores superiores del ordenamiento jurídico, conforme a los cuales va a desenvolverse, y se impregna de la justicia propia de su preponderancia. La 
persona, ante todo, coexiste con los individuos y grupos que disfrutan de la paz social de un orden político avalado por el Estado social y democrático de Derecho. También colabora al armonizar sus perspectivas y orden de preferencias -único escape de quien, en este mundo, cumple la sentencia que le ha condenado a ser libre- con el respeto a los derechos de los otros. Participa, en fin, de la utilidad de los bienes sociales, gracias a la inviolabilidad de sus derechos o exigencia de que se satisfagan en la forma específica que conviene a su identidad y contenido.

\section{Significado económico de la sociedad avanzada}

La promesa de establecer una sociedad democrática avanzada —constante en la dec. 5 Pr. CE - da a entender que no se considera tal la organizada de presente en el Estado social y democrático de Derecho, sino la que — haciéndola mejor y más auténtica — pretende superar la respuesta del constituyente a unas aspiraciones que la carta política cumple de manera precaria. Circula, entre líneas, la especie de la provisionalidad o función de acondicionamiento de un texto constitucional más conservadurista que la futura demanda de una sociedad de ese carácter. La planificación económica - que es, para el art. $38 \mathrm{CE}$, una de las alternativas de un sistema de pluralismo político- se convierte, si el propósito radical prevalece, en un soporte del edificio de la sociedad avanzada. La libertad de empresa en el marco de una economía de mercado — sancionada en el art. $38 \mathrm{CE}$ - pierde oportunidades si se opta por una salida cuyo dogmatismo la destierra o reduce a proporciones insignificantes. La iniciativa pública en la actividad económica — que, sorteando el principio de subsidariedad, anuncia el art. 128.2 CE- deviene regla general, asumiendo el protagonismo de los procesos productivos o multiplicando las normas de Derecho necesario en materia de orden público económico. La predicción del art. 129.2 CE — devaluada por los agentes del consenso constitucional y distante del enclave que, por derecho propio, le correspondía en el tít. $2 .^{\circ}$, cap. I CE - debe absorber los afanes de una sociedad invitada a usar con abundancia de esas fórmulas participativas.

El entendimiento de los pasajes constitucionales en función de la dec. 5 Pr. CE sería el peculiar de un texto expuesto a correcciones crecientemente provocadas - algo interpretativamente audaz y novedoso- por una realidad social que, en vez de coincidir de presente con el momento de aplicación de sus preceptos, es la previsión de un futuro en pro de cuyo advenimiento se defiende la lectura comprometida y radical de todos ellos. La carta política cobra una interinidad justificada por su intermediación en el tránsito al modelo social de un verdadero 
cambio dogmático y orgánico. El proyecto de establecer una sociedad avanzada cuestiona incluso la forma de Gobierno fijada en el art. 1.2. CE y se pregunta por las ventajas o inconvenientes de su sustitución.

Los preámbulos legislativos resumen los avatares del proceso de puesta en la ciudad de la normas jurídicas que introducen, confiesan los objetivos o exigencias de la demanda social justificante de su promulgación y, si es del caso, resumen los reparos o dificultades que se han superado en uno u otro sentido, cuando no se ha acudido, para resolverlos, a transacciones lesivas de los bienes que se sacrifican. A medida que lo acelerado - por no decir que fulminante- de las transformaciones sociales requiere usar del elemento históricoevolutivo de interpretación, crece el riesgo de que preámbulos harto sinceros o confidencialistas digan más de lo que razonablemente deben sobre una voluntad del legislador que acaso tiene sus horas contadas. Voluntad en trance de esterilizarse si - habiendo partido de una realidad limitada por las escaseces de una visión originalista y huérfana de sentido profético — va ser reemplazada, de inmediato o en breve plazo por una voluntad de la ley que actualiza — modernizándole — su mensaje de acuerdo con la realidad y/o la solidaridad social. Ocurre así hasta el punto de advertir que no es desatinado el abstenerse de prologar las leyes expuestas a esta clase de transformaciones.

Ahora bien, la realidad social que la dec. 5 Pr. CE parece desear, queda definitivamente desechada como posibilidad y experiencia de futuro. El nuevo rumbo de los países ex-socialistas priva de prosperidad a esa apuesta y disipa las esperanzas puestas en sus frustradas predicciones. La introducción a la carta política deja en el camino su esfuerzo de denuncia profética. Poco puede, en parte, como animadora de un futuro constitucional que no llegará nunca.

\section{Valores superiores del ordenamiento jurídico y valores económicos}

Hay algo más. Ese proyecto radical desplazaba al cuerpo intraconstitucional de valores del TPCE, llamado a proyectarse sobre el todo de la legalidad fundamental. Así resulta de su carácter de pasaje de privilegio y de su cometido informador. De haber prevalecido la consigna de la dec. 5 Pr. CE, las innovaciones más audaces del TPCE — cuales las constantes en los arts. 1.1, 7 y 9.2 CE- iban a verse desbordadas por otras de corte radical y a tacharse de incompletas y tibias.

El TPCE vence los prejuicios economicistas al reconocer que la comunidad se organiza en el Estado gracias a un sistema de valores superiores integrados en un bloque de moralidad legalizada. Buscando cierta 
sonoridad semántica, la lista de los mismos —metodológicamente heterogénea- empareja conceptos que, unas veces, están en relación de género a especie y, otras, en conexión de medio a fin. El canon axiológico del art. 1.1 CE exalta la justicia como una sintesis de libertad e igualdad o, por mejor decir, del progreso y expansión de la primera - en grado dependiente de los estímulos y méritos individuales- a partir de la segunda. No de la reducción - en pro de una igualdad malinterpretada y mezquina - del espacio que insustituiblemente debe ocupar la libertad, de la que el pluralismo político es un episodio o accidente. El art. 1.1 CE quiere decir que la voluntad fundamental del Estado social y democrático de Derecho aspira a una actuación de los poderes públicos justificada por la finalidad de organizar la vida de la sociedad conforme a objetivos morales. El Derecho deja de ser, para el legislador constituyente, un mínimo ético y se convierte en una de las expresiones óptimas de moralidad secular.

La causa de la economía pertenece a un ámbito de valores inferiores y supeditados a los que ensalza el art. 1.1 CE. Sólo el art. 7 CE - definidor de las libertades colectivas de los sindicatos y las asociaciones empresariales como contribución a la promoción y defensa de los intereses económicos y sociales que les son propios- confiere a lo económico un significado tornadizo, según que afecte a la actitud y perspectivas de uno u otro de esos poderes de hecho. Los empleadores miran a un interés económico químicamente puro, que, aun cuando sazonado con el ingrediente de la función social de la libertad de empresa, coincide con la persecución del beneficio compensatorio de su riesgo inversor. El sindicato debe afrontar un interés económico cuya protección exige mejorar las condiciones de vida y de trabajo de sus afiliados o de los miembros de otras colectividades - mayoritariamente pobladas por trabajadores y portadoras de las más varias demandas sociales - o evitar que las consecuencias de la instalación en la crisis graviten sobre aquéllos con intensidad desproporcionada a su falta de responsabilidad en el origen de ese estado de cosas y a lo injusto de que paguen la factura de sus consecuencias.

\section{Cláusula transformadora y social}

El art. 9.2 CE - más tenue y descomprometido, pese a su valiosa posición sistemática, que el art. 3 II CE, del que, sin apropiarse el todo de voluntad transformadora, trata de imitar las maneras- declara que corresponde a los poderes públicos — además de sujetarse a la legalidad fundamental y al resto del ordenamiento jurídico (art. 9.1. CE)- pro- 
mover las condiciones conducentes a la libertad e igualdad efectivas y remover los obstáculos opuestos a su adquisición por los individuos y grupos sociales. La aspiración liberadora clama por la efectividad que añade algo a la realidad de las libertades superadoras de su carácter formal o mera posibilidad abstracta, sin oportunidad tangible de ejercicio. La acción transformadora apuesta por la causa de la economía cuantas veces ésta exija determinaciones sin las cuales la efectividad se inutiliza. La acción transformadora se enfrenta - aunque los acontecimientos revelen otras actitudes - a la causa de la economía cuando los agentes sociales y los poderes públicos regresan a un discurso indigerible - híbrido de literatura neoliberal y determinismo económico- para entrar en un ciclo de perversión que, guardadas las distancias, recuerda el de la sucesión de las formas rectas de gobierno por sus versiones degeneradas o corruptas.

La cláusula transformadora y social del art. 9.2 CE institucionaliza la revolución desde el interior del sistema democrático. La ejecución de su consigna - que, si no es atinada, constituye una contrafigura o desvarío del despotismo ilustrado e inspira muchas aberraciones - tolera sacrificios de la libertad y la igualdad — no más allá de lo que la respetabilidad de su esencia consiente- en pro de las exigencias de la economía. El art. $38 \mathrm{CE}$, que así lo establece, plantea la necesidad de soluciones de excepción que la instalación de la crisis obliga a multiplicar, siempre y cuando se cuente con la dosis de cordura precisa para guardar tan delicado equilibrio. Abundan las dificultades con que se tropieza para lograr la entrada en juego de la acción transformadora, si los mismos poderes públicos no cuidan de adoptar medidas positivas que la materialicen.

Cuantas veces las demasías oficiales deprimen la causa de la libertad y la igualdad en pro de tesis o proyectos economicistas, la coartada que respalda sus maniobras — sistemáticamente asociada a la flexibilidad del decisionismo político o al interés general, en vez de alguno de los intereses generales que cabe individualizar-impide que, salvo el supuesto límite de una evidente degradación o falsificación de ideas tan cómodamente manejadas, se consumen operaciones axiológica y deontológicamente aconsejables. A saber, las de reprobar, en nombre de lo sensatamente justo, algo que, casi siempre obedece a un juego -ingeniosamente administrado - de sofismas, equívocos, augurios catastrofistas y medias verdades. A ello se suma el que - gracias a los éxitos y adquisiciones del consenso- haya sendas variantes de sentimiento constitucional — respectivamente rigorista y laxista - al tiempo de apreciar y sancionar los atentados contra la legalidad fundamental. Sus violaciones son agresiones de grueso calibre, fácil comprobación y cómodo diagnóstico, mientras que los abusos deshonestos se reputan pecados veniales, conse- 
cuentes con el compromiso de respetar cada uno de los reductos en que el pluralismo político se muestra intransigente.

El control del decisionismo económico en nombre de los valores superiores del ordenamiento jurídico no es fácil, pues la lectura de su proclamación puede parecer minimalista y exenta de ambiciones morales. El art. 1.1 CE complica la estructura piramidal de ese ordenamiento, basada en la idea de que era inoportuno e inseguro admitir un de control suprapositivo del mismo. Las operaciones de constitucionalización y codificación trajeron al Derecho - que no iba a necesitar de esa censura- lo mejor y más universal de las ideas jurídicas acogidas y divulgadas en los países civilizados. Las constituciones se legitimaban por su perfección jurídicoformal y por el dato — que otorgaba robustez y sentido al sistema en ellas inspirado- de ser normas hipotéticas cuya validez fundamental no se podía poner en tela de juicio sin correr el riesgo catastrófico de desmoronamiento de todo el edificio normativo. Ninguna consideración de justicia material debía pesar - en el entendimiento tácito de ser lo mejor enemigo de lo bueno- a la hora de discutir un contenido que además se justificaba por la incondicionalidad con que el pueblo soberano - titular originario del poder político- le había reconocido y hecho suyo.

\section{Lecturas del art. 1.1 CE}

$\mathrm{El}$ art. 1.1 CE reemplaza esa estructura por la que proclama la eminencia - no en vano les denomina superiores - de un haz de valores cuya enumeración - no exhaustiva y susceptible de completarse con otras precisiones - les inscribe en un marco de moralidad legalizada. No se trata de imponer al constituyente un mecanismo de control externo al poder que - sin cuestionar aquí y ahora las objeciones hechas a su delación por otra de un uso alternativo del Derecho autoritario - se le confirió para elaborar la carta política, sino de introducir, en nombre de la ética, una consigna de moderación que empieza por imponerse al legislador fundamental. La opción es llamativa desde el momento en que esa serie de valores - animadores del propósito de vivir conforme a justicia y no sólo con apariencia ordenada - se consideran superiores y antepuestos a los inferiores de que son parte los contenidos económicos significativamente confinados en el título VII CE (Economía y Hacienda).

El modo que los valores superiores del ordenamiento jurídico tienen de primar sobre los inferiores de naturaleza económica, difiere en función del entendimiento del art. 1.1. CE. Si el constituyente ha pretendido enfatizar el designio moralizador de su proyecto y no modificar la clásica 
estructura del ordenamiento jurídico, el art. 1.1 CE está diciendo que, a causa de la delicadeza de estas intenciones, todos y cada uno de los preceptos del texto constitucional son la óptima síntesis y/o la más rigurosa expresión de los valores asumidos. Su invocación se convierte en la pública proclamación de una finalidad política inseparable del norte de exquisita moralidad que la inspira. La ordenación de los temas económicos no puede ser entonces algo deontológicamente discutible, sino que ha de plegarse a los imperativos del sistema de valores así reconocido y prestigiado.

Otra lectura del art. 1.1 CE sugiere que el constituyente predijo una finalidad a la que se esmeró en ser fiel mientras duraba el proceso constitucional, pero de cuyo acabado cumplimiento no se puede certificar sin más de una reserva. Admite y prevé —quizás ante las capitulaciones y sacrificios de bienes valiosos que provocó el uso del consenso- que ciertos puntos de la carta política - fruto de la reducción de muchas contradicciones - no se condigan con las reclamaciones morales que encabezan su texto. Declara, frente a este riesgo de falibilidad, la exigencia de que esas flaquezas se corrijan con soluciones interpretativas ajustadas al dictado de los valores superiores y que su influjo se propague a los pasajes constitucionales que adolezcan de tal insuficiencia.

Es significativo que el art. 1.1 CE haya renunciado a emplear expresiones que, cuales la de proclamar o declarar, muestren la inevitabilidad solemne con que afirma la primacía de los valores superiores del ordenamiento jurídico. Consciente de las debilidades que, como se ha dicho, puede acusar la ley fundamental a causa de las circunstancias de su producción, el constituyente prefiere servirse del verbo propugnar, menos triunfalista y más acorde con la presencia de anomalías corregibles a través de los valores superiores. No hay diferencia, desde tal perspectiva, entre éstos y los principios generales del Derecho que - ya a tenor del p. 10 EMTPC.c y del art. 1.4. Cc- informan el ordenamiento jurídico, porque preceden a un Derecho positivo que ha de inspirarse en ellos y cuyo control debe ejercerse en su nombre.

La reflexión se funda en la idea de que el ordenamiento jurídico sólo consta de normas positivas y no admite elementos suprapositivos o axiológicos. Su resto - aludido en el art. 9.1 CE para imponer a los ciudadanos y a los poderes públicos un deber general de sujeción- queda, en tal caso, reducido a los contenidos que, en un pasaje sistemáticamente inadecuado (tít. VIII CE), el art. 149.1 CE dedica a situar los diversos sectores de la legislación material o suma de legislación formal y desarrollo reglamentario; además de las manifestaciones normativas de la CCAA. La perspectiva implica que los valores superiores - aun cuando el art. 1.1 $\mathrm{CE}$ les considera del ordenamiento jurídico y da a entender que pertene- 
cen a su totalidad- son extrínsecos a su esfera y sirven, a lo sumo, para corregir - mediante técnicas de aplicación individualizada del Derecho- las disfunciones de las normas constitucionales u ordinarias que se alejan de su mensaje moralizador. Su impacto sobre las regulaciones económicas se ha de entender entonces con las limitaciones propias de esta modestia conceptual.

La comprensión axiológica por excelencia del art. 1.1 CE proviene de su lectura inmediata e indica - como el empleo de la contracción del pone de manifiesto con relación al sustantivo adjetivado que le sigueque los valores superiores no viven fuera del ordenamiento jurídico en cuya cima piramidal figura el texto constitucional, sino que se sumergen en su seno y ocupan el espacio del que desplazan a la norma hipotética fundamental. Se propone una estructura del ordenamiento por la que las normas constitucionales — preceptos y principios extraídos del contexto sistemático de la carta política o resultantes de su interpretación- no cuentan con una presunción irrefragable de moralidad y pueden inaplicarse en nombre de su contradicción con los valores superiores. Todo un cuerpo de doctrina sobre la desertificación constitucional y el modo de enmendarla descansa en estas posiciones. Cosa distinta y trabajos más arduos son los de encontrar el instrumento tecnicojurídico que permita operar de acuerdo con sus planteamientos. La asimilación de un criterio de censura de la moralidad secular de la carta política favorece la crítica de las soluciones economicistas que, adoptadas por el constituyente, dejan de atenerse al imperio de los valores superiores del ordenamiento jurídico o, para ser más simple, al dictado de lo justo. Las licencias semánticas del art. 1.1 CE — al mencionar por separado la justicia, la libertad, la igualdad y el pluralismo político- no impiden la conclusión metodológica de que el primero de dichos valores sintetiza los dos que le siguen, y que el último - muy sensible a causa de la experiencia constructiva del edificio constitucional - es un apéndice o variante de la libertad que le precede.

\section{8. ¿Moralización de la economía?}

Aun compartiendo la más ambiciosa de estas tesis, es directamente proporcional a su relevancia y aprecio la dificultad de trasladar a la práctica jurídica la aplicación de sus proposiciones. Si cabe una lectura óptimamente moralizadora de la ley fundamental, el pluralismo político no condena las que empequeñecen esa posibilidad. El control de las decisiones —oficiales y particulares - de signo económico que atentan contra el haz de valores superiores del ordenamiento jurídico y privan 
de justicia a parcelas respetables de la vida individual y social, puede intentarse en nombre de conceptos moralmente indiscutibles y perfectos - porque cuesta imaginar un reconocimiento del valor-justicia más cualificado que el de su expresa constancia constitucional- y normativamente insuficientes, por falta de cauces eficaces para lograr su prevalecimiento.

La inmunidad de los actos oficiales de decisionismo económico - consecuencia de las anteriores consideraciones- se explica por el interés del poder político en no sufrir descrédito a causa de la eventual inmoralidad de esas determinaciones. Si antaño la seguridad y la estabilidad del Estado dependieron de su suficiencia coercitiva para neutralizar las agresiones dirigidas a su dislocación y derribo, su prestigio actual ante la sociedad está en función de una dirección acertada de la marcha de la economía. Si las condiciones de emergencia económica o las circunstancias menos prósperas obligan a ello, el poder constituido suele invocar una novísima razón de Estado para adoptar medidas cuya dosis de arbitrariedad e impopularidad es tan gruesa como parca la posibilidad jurídica de impugnarlas. Decisiones que no están exentas de afinidad y connotaciones con la vieja teoría de los actos políticos.

Dicha figura - justificada por exigencias de la razón de Estado y pensada para hacer eficaces las consignas tendentes a inmunizar las demasías del poder - escapaba a los esfuerzos de censura que, en nombre de las normas de Derecho objetivo, trataban de controlar sus proteicas manifestaciones. Aunque en ello no se haya reparado, la doctrina de los actos políticos era trasposición o reflejo hereditario de una de las interpretaciones que la teoría del Estado absoluto había ensayado al defender que, de todas las acciones y proyectos humanos, los relativos a la decisión política ocupaban un campo extraño a las percepciones de la ética y que no era conceptualmente atinado hablar de su moralidad, sino de su extramoralidad o indiferencia a las pautas y objetivos de transformación deontológica.

El título VII CE (Economía y Hacienda) no es en vano un pasaje de máximo carácter programático —al señalar orientaciones robustecedoras del decisionismo estatal y carecer de cláusulas garantizadoras de los derechos individuales y colectivos cuyo legítimo interés puede verse afectado- y un ámbito de irresponsabilidad para el poder público que, pese a la declaración del art. 9.3. CE, no soporta ninguna consecuencia de las acciones u omisiones que, lesionando aquéllos bienes, le son imputables. Muchos actos económicos - cuales los obedientes a opciones doctrinales que, como el funesto fundamentalismo monetarista, son técnicamente abominables y escapan al control de los principios y preceptos constitucionales- refuerzan el convencimiento de que la autoridad es, cada vez. 
más, un poder sin fronteras y no un deber de mandar según razón. Impunidad que estimula la multiplicación de los errores y destituye de la sensibilidad crítica precisa para prevenir aquéllos en que impunemente puede incurrirse de futuro.

Los controles que, con escasa posibilidad de coerción, puede ejercer la comunidad internacional sobre el decisionismo económico interno, gozan de una publicidad limitada y se ejercen en términos tan complacientes y tecnificados que, salvo contadas excepciones, no conmueven a la desorientada opinión pública. Ello, sin olvidar el reparo de que la sociedad es informada del planteamiento y solución de esos problemas con datos macroeconómicos y apreciaciones críticas que ha de aceptar en virtud de un acto de fe incompatible con la dosis de justificado recelo que despierta el dogmatismo de esa supuesta información veraz. No es entonces fácil reaccionar mediante acciones sindicales - cuya es el libertad de emprender iniciativas en pro de las necesidades de cualesquiera grupos sociales presumiblemente compuesto de una mayoría de trabajadores-o procedentes de otros focos de la sociedad pluralista aludida en los arts. 7 y 20.4 CE.

\section{Principios rectores de la política social y económica}

Especial análisis merece la correlación apreciable entre el cap. 3. ${ }^{\circ}$, tít. I CE (De los principios rectores de la política social y económica) y el tít. VII CE (Economía y Hacienda). ¿Cómo, a juzgar por la semejanza de sus rotulaciones respectivas, comparten uno y otro pasaje la consideración de lo económico?

El primero desgrana las consignas que los poderes públicos deben poner en práctica para ultimar el esfuerzo de transformación - anunciado por el art. 9.2. CE- en las parcelas de la vida social a que el constituyente dedica una atención justificada por la preferencia de sus necesidades. No en vano las ideas de asegurar, promover, fomentar, velar por y tutelar se manejan para designar los objetivos a que esa especial solicitud se aplica. Ahora bien, ninguno de dichos principios insinúa el germen de nuevos derechos constitucionales que difieran de los reconocidos previamente en las secs. $1 .^{\mathrm{a}}$ y $2 .^{\mathrm{a}}$, cap. $2 .^{\circ}$, tít. I CE, ciñéndose a especificar anticipos de su contenido esencial o núcleo invulnerable y a insistir en la urgencia de su desarrollo. Sería una interesante operación la de vaciar de contenido el cap. $3 .^{\circ}$, tít. I CE y trasladar sus principios a los preceptos respectivos que están bajo las rúbricas De los derechos fundamentales y de las libertades públicas y De los derechos y deberes de los ciudadanos. De ello se seguiría la desaparición del pasaje - ins- 
trumental y estimulante- en que se alojan unos principios migratorios conexos con el derecho o libertad cuyo desenvolvimiento encarecen y esbozan.

Es de advertir que los llamados principios rectores no se refieren, de una parte, a materias propias de la política social y, de otra, a problemas concretos de la política económica, pues, de ser así, el sustantivo política se habría expresado en plural para adecuarse a los predicados respectivos. Sus previsiones participan de ambos caracteres. Constituyen principios de política social que adelantan criterios sobre la promoción de la libertad y la igualdad de los grupos de la comunidad directamente acreedores al avance de transformación. Conciernen a la política económica, porque - además del apoyo de los poderes públicos al ejercicio de los derechos o la realización de las libertades que incorporan- su ejecución requiere el concurso de medios materiales y auxilios financieros que han de aplicarse con la incondicionalidad peculiar de la preferencia otorgada.

Sólo el art. 40.1 CE se refiere a una política de estabilidad económica que no tanto se alienta como orientación técnica, cuanto en calidad de pauta moral-por algo quien no vive no se redime- inspiradora del juego de los principios comprendidos en el cap. $3{ }^{\circ}$, tít. I CE. No se dice cómo debe funcionar la economía para ser estable, pero se advierte que debe operar establemente para que los mecanismos de justicia social no adolezcan de inseguridad o incertidumbre. Las medidas previstas del art. $41 \mathrm{CE}$ en adelante, se consideran tan urgentes que no se supeditan, en más o en menos, a restricciones o pretextos economicistas. Otra cosa rompería la correspondencia entre la posibilidad material y la justicia de un orden que — siendo, a la vez, social y económico — sólo se atempera al Derecho si respeta escrupulosamente la relación de medio a fin que entre lo económico y lo social debe darse para no atentar contra la dignidad de la persona (art. 10.1 CE).

La conclusión resulta de la rúbrica del cap. $3 .^{\circ}$, tít. I CE. Si la mención de lo económico forma parte de ella y de este aspecto nada dicen las proclamaciones de los respectivos principios rectores, es porque, en virtud de su encabezamiento, se presupone que las previsiones financieras -necesarias para iniciar y llevar a buen fin los proyectos de transformación- se han de hacer con continuidad y amplitud que no menoscaben lo más mínimo la efectividad de lo propuesto. Ello sólo se alcanza concentrando en la ejecución de tales fines los recursos económicos bastantes para atenderlos sin sujeción a pautas de limitación o subsidariedad. Todo lo contrario del virus de desentendimiento social que encandila a los poderes públicos del Estado de bienestar en trance de liquidación. 


\section{Manipulación del interés general}

El título VII CE parece pensado para dificultar los controles que, en nombre de la juricidad, pueden actuar sobre las decisiones económicas. La cláusula - constante en el art. 128.1 CE— de subordinación de la riqueza nacional al interés general hace de este concepto jurídico indeterminado un resorte de formidable inmunidad para los excesos del poder público consuma en ese orden de cosas.

Si la comprobación del interés social — contemplado en el art. 33.3 $\mathrm{CE}$ - requiere una individualización mínima de la colectividad portadora y una concreción de las circunstancias en que sus valores se ven amenazados o agredidos, el determinar, por esta misma vía, si se dan condiciones de interés general - el cambio de adjetivo es trascendenteresulta poco menos que misión imposible. La quiebra del interés general puede apreciarse en situaciones-límite que, al velar la existencia de intereses particulares, acreditan la falta de aquél a todas luces, pero, salvo contados casos, la denuncia de las situaciones ayunas de interés general se halla condenada al fracaso frente a la presunción de acierto que contra lo abrumador de las verificaciones estadísticas - unge la acción de los poderes públicos. Más que del interés general — precedido de un artículo determinado cuya utilización no se condice con el pluralismo de la sociedad (art. 20.4 CE) — debe hablarse de alguno de los intereses generales o de un interés general precedido de un artículo indeterminado y equivalente a la noción de bien común que el constituyente soslaya para eludir compromisos de escuela o connotaciones éticas demasiado inmediatas.

El bien común - compendiado en la suma de las exigencias de la coexistencia, la colaboración y la coparticipación- se da cuando concurren los elementos necesarios para que la persona alcance el óptimo goce de sus libertades. La cima del bien común coincide con la culminación del esfuerzo de liberación que, según el art. 9.2. CE, corresponde incesantemente a los poderes públicos. Estas categorías no se aplican cuando, sin invocar siquiera el interés general, se adoptan decisiones económicas que deben tenerlas en cuenta y justificarse en su virtud. El interés general es una noción evanescente, cuya dificultad metodológica consiste en lo extraordinariamente difícil o imposible de identificar, fuera de toda duda, al sujeto colectivo que le ostenta y mostrar, no menos convincentemente, el ámbito objetivo en que su deterioro se origina. A falta de una rigurosa verificación, el interés general puede confundirse con todo el proyecto del Estado Social y democrático de Derecho (art. 1.1. $\mathrm{CE}$ ), con la eventual tutela de los valores constituciones (art. 9.1 CE) y — esto es lo deplorable - con los inconfesados propósitos de defender, 
previa su invocación, espacios y oportunidades de poder cuyo temor de pérdida desata la resistencia numantina — digna de mejor causa- que protagonizan quienes ven en peligro su conservación.

La subordinación al interés general de la riqueza de titularidad privada - una de las variantes referidas en el art. 128.1 CE - implica dos notables posibilidades. Una, la de que, en nombre de esa dependencia, los poderes públicos fijen limitaciones genéricas o institucionales al ejercicio de ciertos derechos subjetivos, respetando, como manda el art. 53.2 CE, el contenido esencial de las situaciones afectadas. Otra, la introducción de normas de orden público que limitan la autonomía negocial de los particulares y amplían el marco de las restricciones que prevé el art. 1.255 C.c.

Es fácil concluir que el propósito definidor de lo que se entiende por interés general provoca una contradicción en los términos. Un interés es perceptible cuando se identifica fácilmente al sujeto o grupo portador - porque sólo con relación a uno u otro cabe reconocerlo- y se establece si la legítima apetencia por la utilidad de un bien concreto, ha sido o está a punto de verse contradicha. Es difícil hablar de interés allí donde estas operaciones no pueden realizarse con un mínimo de seguridad y solvencia. El concepto de interés general no parte de una agresión evidente ni de la constancia de un riesgo inmediato, sino que se asocia a un juicio político de oportunidad o conveniencia sobre la adopción de decisiones que dicen prevenir riesgos probables -más o menos difusos y/o lejanos- y que no corresponden a lo que el metalenguaje del Derecho considera interés merecedor de protección. La habilidad semántica —cuyo manejo da entrada en el juego a la idea de interés general- reside en el uso intoxicante del término para prejuzgar, a fuerza de su reiteración, la respetabilidad de cuantas medidas lo pretextan y salvan situaciones en que la ética política impone graves responsabilidades a quienes no están en disposición de soportarlas.

\section{Ingerencia económica y progreso social}

La legitimidad de la intervención del Estado en la iniciativa económica es otra de las proclamaciones que, vertida en el art. 128.1 CE, debe analizarse. La cláusula puede entenderse referida a uno de los modos de proteger la productividad que, al concurrir en el mercado de libre competencia, elige el poder público de acuerdo con el art. $38 \mathrm{CE}$. Relacionada con el art. 131.1 CE, deja intuir un futuro de planificación cuasiautocrática situada en los límites tolerables del valor superior del pluralismo político (art. 1.1 CE). Supone la renuncia a un principio de subsidariedad que, si bien pertenece al depósito cultural de las modernas libertades, se 
disipa ante el énfasis con que el art. 9.2 CE anuncia la intervención transformadora de los poderes oficiales.

La ingerencia estatal se refleja en el poder de producir las normas jurídicas que integran el orden público económico. Las consignas del orden público virtual de este carácter se difunden cuando, sin explícita formulación, ciertas actitudes y/o sugerencias de los poderes públicos inducen a conductas que no tienen opción distinta de la de acatar esas orientaciones. Las recomendaciones o consejos -impartidos, a veces, en tono coloquial o benévolamente didáctico y no por ello exento de propósito conminatorio- que las organizaciones de empleadores multipliquen su resistencia frente a algunas reivindicaciones de la negociación colectiva, no adquieren la fuerza de obligar que resulta de las garantías explícitas en el art. 9.3 CE, pero representan uno de los modos de obrar con que los agentes negociadores introducen una restricción que está en la base de su comportamiento y modifica la presuposición de sus acciones y reacciones. Una sencilla insinuación —cursada, eso sí, con énfasis reveladorcumple función idéntica a la de una norma de Derecho necesario dictada por el Estado legislador.

Bajo apariencias de progreso, el art. 128.2 CE desgrana promesas que, a causa de ciertos episodios críticos de la hechura constitucional, pasaron al tít. VII CE, al devaluarse su impacto social y rechazarse —en régimen de consenso- su adscripción, cuando menos, al cap. 3. ${ }^{\circ}$, tít. I CE. Promover eficazmente las formas de participación de los trabajadores en la empresa - añoranza de la democracia industrial desde que la moda de la contestación y de las adquisiciones cualitativas de la clase trabajadora sintonizó, en su mundo, con las aspiraciones afines de los grupos sociales, las iglesias, la escuela y la universidad, y la familiaera comparecer en dos campos. El primero, propio de las acciones sindicales invasoras de un reducto nuevo - circunscrito al centro de trabajo o el lugar de empleo- cuyos intereses requerían inventar estructuras distintas y superadoras de las que, anquilosadas por el simplismo estratégico del sindicato clásico, no resolvían los problemas causados por la traslación a aquellos ámbitos de las manifestaciones álgidas del conflicto industrial. El sindicato del art. 7 CE no es sólo el agente social de los grandes espacios - organizado en régimen de democracia delegada para amparar el interés de los trabajadores de una industria o rama de producción-e incluye las variantes de base asamblearia que forman cuantos individuos - ligados al mismo empleador por los respectivos contratos de trabajo - se exponen a las demasías del poder de organización. Participar es, desde esta perspectiva, dar con las estructuras aptas para hacer efectivas unas formas de representación que, andando el tiempo, adoptan, con el fin de racionalizar su funcionamiento y mejorar sus resulta- 
dos, los esquemas de la democracia delegada. El derecho a participar nace de la posesión de un factor productivo - la fuerza de trabajo- que constituye el título colectivo de su adquisición y del contrapoder moderador que lleva consigo.

Otro es el caso de la participación natural que no se debe a una innovación cualitativa de progreso y sí al acceso de los trabajadores a la propiedad de los instrumentos y medios de producción. Las proposiciones del art. 122.2 CE se encadenan conforme a una línea de pensamiento razonable. La participación cualitativa es la primera fase o incoación de un proceso que ha de cerrarse con el advenimiento a esa propiedad. Las coordenadas históricas de entonces — simplificadas actualmente- autorizaban las alternativas - soportadas por el valor superior del pluralismo político (art. 1.1. CE) — de una solución afín a las de las comunidades ex-socialistas, si la propiedad se confundía con la disposición colectiva de los bienes, o consistente en el ejercicio de la libertad de empresa que sanciona el art. $38 \mathrm{CE}$. Establecer los medios pudo querer decir una u otra cosa.

\section{Planificación y política económica}

El Estado no se ha servido hasta el momento de la fórmula que el art. $131 \mathrm{CE}$ le procura para planificar, en interés de las necesidades colectivas, la actividad económica general. El dato de no haberse erigido el organismo que el art. 131.2 CE requiere formar para el éxito de las operaciones planificadoras, da idea de la falta de voluntad política a la hora de perfeccionar una infraestructura suplantada con la imitación nominalista de un ente consultivo al que se ha denominado económico y social, pero cuyas competencias no son las queridas, con ese fin, por el constituyente. El que la planificación democrática de la economía -impracticable sin la mediación de un organismo constituido a tal efecto y la cooperación responsable de todos los agentes sociales- se considere una tarea de aplazamiento indefinido, denuncia el tono arbitrista los de las soluciones adoptadas para conjurar problemas económicos de primera magnitud. Menudean las recetas domésticas empeñadas en templar el ritmo del recalentamiento de la economía con medidas tomadas a préstamo del depósito del fundamentalismo monetarista. La utilización de sus principios - defensores de un alza de los tipos de interés que reduzca la masa de dinero destinada a la inversión o al consumo y contenga su velocidad de circulación - ha pretendido remediar, sin éxito, los desmanes causados por una espiral inflacionaria que desautoriza sus prevenciones y terapias. Cuesta hoy hablar de una planificación que conceptualmente se predica 
mal de los niveles de decrepitud y atonía en que se ha situado la actividad económica.

Un subrogado de la planificación económica —extraño a lo previsto en el art. 131.1 CE - es el acervo de medidas que el PCR, consiguiente a la suscripción del TUE, establece con la finalidad de ser Europa. La marcha de los acontecimientos no permite optimistas predicciones sobre consecución de los objetivos que deben alcanzarse para acceder a la tercera fase de la unión augurada; a saber, una tasa de inflación que no supere en el 1,5\% la de los tres Estados miembros con índice más bajo, una permanencia de dos años en la banda más estrecha del sistema monetario europeo, un déficit público no desproporcionado ni excesivo y un tipo medio de interés nominal que, a largo plazo, no exceda en más de un $2 \%$ al de los tres países más estables en materia de precios. Objetivos cada vez más distantes y casi desactualizados.

La racionalización dimanante de una política económica — bien argüida, convincente y anterior a los dictados de las instancias supranacionales- exigía un serio compromiso del Parlamento competente para definirla. Las características numerales de las minorías en él representadas han trastornado la acción de los poderes a cuyo cargo está la realización de la política económica. El Parlamento debe fijar sus líneas generales —proveyendo a su definición-y al Gobierno incumbe, una vez definida, ocuparse de su dirección. Semejante reparto de papeles no ha sido respetado. La política económica no ha resultado de un debate que, como todas las cuestiones de Estado, resuma - cooperativa y constructivamente - las aportaciones de cuantos, con su iniciativa o su crítica, responden ante la sociedad del éxito o fracaso de las medidas que deben integrarla.

No es defendible que la llegada de la planificación al art. 131.1 CE fuera una de las operaciones flexibles con que la técnica del consenso quiso complacer a las posiciones radicales que, puesta la vista en los experimentos de la Europa oriental, reclamaban su reconocimiento. Un uso democrático — cuya oportunidad quedó atrás - del art. 131.1 CE habría excitado el sentimiento de responsabilidad de los gobernantes, sensibilizándoles a la dificultad de una tarea que, aún cuando fatigosa y expuesta a imperfecciones, demandaba un imponente esfuerzo de moralidad. Habría incoado y - lo que es más apreciable- convertido dicho compromiso en algo duradero. Habría suscitado el aliento y la contribución de muchos sectores sociales, animados por las perspectivas de una planificación pluralista y solvente. Habría acrecentado el crédito del Estado ante la sociedad y los foros internacionales.

Las responsabilidades de la política económica se han liquidado asegurando, conforme a la pésima tradición maniquea, que fuera de ella no 
existe salvación. Lo que, si se analiza con delicadeza, dista de garantizar que el éxito resida en aplicar sus soluciones. Se han rehuido, con descalificaciones y evasivas, objeciones técnicas valiosas y desinteresadas. Se ha despreciado la colaboración de instituciones y grupos cuya audiencia era de todo punto indispensable. El decisionismo económico se ha resentido de ingredientes antidemocráticos que, si su fracaso no bastase para desautorizarlo, estarían en vanguardia de las acusaciones conducentes a la más enérgica condena de sus métodos.

La sustracción al Parlamento de competencias sobre política económica se consuma incluyendo en los Presupuestos Generales del Estado normas cuya finalidad va más allá del propósito de justificar la expresión cifrada de ingresos y gastos en que aquéllos consisten. La reiteración de un precepto temporal durante anualidades sucesivas hace temer que la misma regulación, no constituye el resultado de una previsión hecha para ese período y sí el fraccionamiento artificioso de una medida proyectada a largo plazo $\mathrm{y}$, como tal, falsamente divisible. $\mathrm{Si}$, cual es propio de su generalidad o designio duradero, dicha norma hubiese provenido de una discusión parlamentaria sujeta al procedimiento general de elaboración de las leyes, el pleno ejercicio del poder legislativo garantizaría la detención y profundidad de un debate exento de restricciones a la facultad de presentar, defender y criticar enmiendas. Esta amplitud de conocimiento se defrauda si las medidas de política económica que el Parlamento debe analizar - para acordar su impertinencia o propiedad a largo plazo- se ocultan bajo la sucesión de disposiciones anuales contenidas en los Presupuestos Generales del Estado, que así escapan a la fiscalización parlamentaria, pues el art. 134.6 CE requiere la conformidad del Gobierno para tramitar las proposiciones o enmiendas que, como las concernientes a ese aspecto, supongan aumento de ingresos o disminución de gastos del sector público estatal.

\section{Consolidación conceptual de la libertad de empresa}

Procede, en fin, reflexionar sobre el art. $38 \mathrm{CE}$, que reconoce la libertad de empresa en el marco de una economía de mercado y cuya lectura pudo, en su momento, ser doble a la luz de este complemento circunstancial. Si se entiende que la elección de dicho marco era una condición indispensable de aquella libertad, pero no desautorizaba diseños económicos que prescindiesen de ella, cae de su peso que podía excluirse si se optaba por alguno de los modelos que, dentro de su discutible democraticidad, la proscribían. Si la referencia se entendía hecha al único marco admisible constitucionalmente para el desarrollo de la actividad económica, la liber- 
tad de empresa descartaba cualquier otro modelo que la desconociese.

La alternativa se ha desvanecido por circunstancias de hecho y de Derecho. El descrédito histórico — que definitivamente han avalado las experiencias más recientes- de los sistemas socialistas, ha hurtado su espacio a una de las interpretaciones propuestas. La inserción en un marco de economía de mercado caracterizado por convertir la libertad de empresa en un derecho fundamental - como ocurre en el ámbito comunitario- desautoriza una elección proscrita por la técnica de interpretación utilizable para fijar el alcance y contenido del art. $38 \mathrm{CE}$.

El art. 10.2 CE fija, sin afán exhaustivo, criterios de interpretación e integración que activen los efectos útiles de los preceptos relativos a derechos fundamentales y libertades, sin adjetivación. No es preciso que se trate de libertades públicas y, así las cosas, la libertad de empresa pasa a beneficiarse de esos auxilios interpretativos. El art. $38 \mathrm{CE}$ debe entenderse a la luz de los tratados y acuerdos internacionales que, en materia económica, se hayan ratificado por España. No es dudoso que los textos de esta naturaleza — sucesivamente asumidos por el Estado español- en el medio comunitario presuponen un sistema de libre concurrencia y en su función deben fijarse los contenidos de aquella libertad, pues, aun cuando el pluralismo político permita innovaciones o tendencias más o menos imaginativas, la referencia de ese depósito cultural no sólo implica aclaración o complementación — propias respectivamente de la disipación de dudas o de la evitación de lagunas constitucionales- y también juega como un límite de orden público impuesto a cualquier tentativa de situar el modelo económico al margen de tales coordenadas. Los objetivos del art. B TUE - tendentes a lograr el refuerzo y la convergencia de las economías de los pueblos de Europa - facilitan el elemento contextual a cuyo través la libertad de empresa adquiere un significado excluyente de otras alternativas - de corte marxista autoritario- que la entrada en Europa los ha hecho inviables.

Las alusiones a la planificación pierden el énfasis que parecía conferirles el entendimiento radical del art. 38 CE. Daban la impresión de que, al no adjetivar esa planificación de democrática, se apuntaba —como salida rotundamente augurada por el complemento circunstancial... en su caso...- el desenlace consistente en una solución máximamente autocrática de las cuestiones económicas, si así lo requerían las circunstancias del momento. Se advertía de que no había fronteras al ensayo de soluciones planificadoras y que éstas podían diversificarse hasta donde, llegada la ocasión, lo aconsejase la defensa de la productividad. Semejante discurso se ha desvitalizado. El que, en su caso, esa defensa se acometa mediante la planificación, cobra un sentido acorde con la sobreviviencia del único modelo económico que sustituye a la anterior posibilidad de optar 
entre dos o más de ellos. Quiere decirse que, si circunstancias excepcionales lo demandan, el contenido esencial de la libertad reconocida en el art. $38 \mathrm{CE}$ puede restringirse en defensa de una productividad que, como concepto jurídico indeterminado, tanto puede orientarse a proteger el interés empresarial, si se repara en los aspectos del ejercicio del derecho que le benefician y se identifican con sus tradicionales contenidos, cuanto el de los trabajadores, si se atiende a las cargas que, para proveer a su función social, llevan consigo la propiedad de los instrumentos y medios de producción, y el poder de organización que racionaliza su empleo.

\section{Abreviaturas y siglas}

art.

cap.

CCAA

$\mathrm{CE}$

CI

dec.

EMTPC.c.

PCR

Pr. CE

sec.

tít.

TPCE

TUE artículo.

capítulo.

Comunidades Autónomas.

Constitución española de 27.12.78.

Constitución Italiana de 27.12.47.

decisión.

Exposición de Motivos de la L. 31.5.74, de reformas del Título Preliminar del Código Civil.

Programa de Convergencia Real.

Preámbulo de la Constitución española.

sección.

título.

Título Preliminar de la Constitución española.

Tratado de la Unión Europea (7.2.92). 